\title{
Souvenirs and Community Participations as a Support to Tourism Attractions in Ciapus, Bogor
}

\author{
Nungky Puspita ${ }^{1}$, and Hindun Nurhidayati ${ }^{2}$ \\ ${ }^{1,2}$ Universitas Pancasila, Jakarta, Indonesia \\ Email: ${ }^{1}$ hindunsugiarto@gmail.com
}

\begin{abstract}
The tourism industry cannot be separated from the tourism components itself, such as Attractions, Amenity, Accessibility, Supporting Facilities and Institution, which are related to each other. Supporting facility such a place to buy souvenirs is an important component because souvenirs include in objects that can be developed and have added value for tourism actors. The absence of souvenirs in Ciapus leads to the need of planning of sophisticated souvenir making to increase the benefits for local communities and how to empower local communities for better understanding in managing and minimizing the impact of such activities. This research used descriptive qualitative research methods where the data were taken through the process of interviewing with community leaders, tourists and managers of attraction sites located at the tourism village of Tamansari in Ciapus, Bogor. The results showed that some souvenirs that have been previously planned got a positive response by consumers who were eager to get distinctive souvenirs from the village. There were two souvenirs in great demand by visitors, namely clothes and handmade products as well as batik-made products such as bags, wallet and hand phone casing.
\end{abstract}

Keywords-Souvenir, Community Participations, Tourism Village.

\section{INTRODUCTION}

The tourism industry cannot be separated from the tourism components itself, such as Attractions, Amenity, Accessibility, Supporting Facilities and Institution, which are related to each other. Supporting facility such a place to buy souvenirs is an important component because souvenirs include in objects that can be developed and have added value for tourism actors.

One of the tourist attractions in Bogor is the tourism village of Ciapus located at the hill of Mount Salak. The main attraction in Ciapus is the 2nd largest temple in Indonesia and waterfall (Curug in Bahasa), but there is lack of souvenir that can be bought by the tourists.

Souvenir is one of the important elements in a Tourist Destination or Tourism Object. It is a common phenomenon when many tourist objects are filled by sellers of Souvenir, Handicraft and other souvenirs. It has become a habit that the tourists buy typical souvenirs from the attraction sites such as key chains, necklaces, bracelets, clothes, pants, hats and various other creative souvenirs that can be an additional income for local people around Ciapus. Therefore, this research was conducted to explore kinds of souvenirs that can be made and sold by the surrounding community to empower the community to avoid being marginalized by investors who are not taking sides at the interests of the local community.

Community-based tourism activity is a solution to reduce the destructive impact brought by tourists and to increase the benefits of tourism activity itself for local people, because the locals know more about the sights. The good and bad the impacts of tourism activities will be gained by local communities, for which this research was conducted. Community-based tourism is a kind of tourism that is de facto planned and managed by an individual/household group comprising the community as a communal business group. Such activities may also be managed by a private company whose activities are organized by the community. Furthermore, a tourism activity can be called as community-based if the locals have strong control and are involved in tourism activities where most, if not all, of the benefits can be acquired by the community. 
Community-based tourism activities can give a contribution and incentives for the protection of nature and culture and provide opportunities to improve people's lives. Therefore, the concept of community-based tourism can exist if the decisions about tourism activities and development are controlled by the local community.

\section{LITERATURE REVIEW}

\section{A. Souvenir}

Souvenirs are handicrafts, which are the result of the creativity of craftsmen who are able to transform wasted and unworthy items into interesting handmade craft products that attract many people, especially tourists. The word souvenir is defined as: "Souvenir is usually small and relatively inexpensive article given, kept or purchased as a reminder of a place visited, an occasion, etc." Meanwhile, in Webster English Dictionary (2004), the word souvenir is defined as "an object a traveler brings home for the memories associated with it."In Bahasa, "souvenirs" are often referred to handicrafts. Perhaps, it is because the family or colleagues often say "please bring souvenirs or handicrafts when you go home" to someone who travels to a place outside his or her homeland. Some reasons underlie how important the position and role of society in tourism management is as follows:

1. The increasing demand of the natural resources generally indicates a great pressure on the role of management by the community.

2. Community-based tourism activities are expected to improve socio-economic conditions of a community.

3. Community-based tourism can fulfill our desire for a cultural identity of society that is expected to inhibit the negative effects of tourism.

4. Community-based tourism can also create a structure of planning, implementation and monitoring of effective tourism activities and to facilitate in determining the scale of appropriate economic activity.

Participation by the community is different in level, due to different scale of activities. Participation is, among others, participation by coercion, participation with power and threats, participation due to encouragement, passive participation and spontaneous participation (Tosun, 2006).

\section{B. Tourism Village}

A tourism village as a rural area that offers an overall atmosphere reflecting the authenticity of the village, both in terms of socio-cultural life, customs, daily activities, building architecture, and village spatial structure, as well as the potential to be developed as a tourist attraction, for example: attractions, food and drinks, souvenirs, lodging, and other tourist needs. Tourism village is a form of integration between attractions, accommodation and supporting facilities presented in a community life structure that blend with the prevailing rules and traditions. A tourism village has a unique attractiveness, which can be in the form of a unique physical environment of the rural environment as well as the socio-cultural life of the community that is packed naturally and attractively so that the attractiveness of the village can invite the tourists to visit the village. There are two meanings about a tourism village: (1) It will be called as a tourism village if the guests stay at night; and (2) It will be called as a village tour if the guests only take a visit. The community is the main driver in the tourism village. The community itself manages the tourism, so that no investor can enter to influence the development of the tourism village itself. If there is a tourism village managed by the investor, it means that the village is not a tourism village in the real term.

Tourism village in a simple meaning is a tourist attraction that has the potential of superior art and culture in a rural area located in the local government. Tourism village is a village that lives independently with its potential and can sell various attractions as a tourist attraction without involving investors. According to the statement above, the development of tourism village is the realization of the law of regional autonomy (Law No.22/99). Therefore, each district needs to make a program on the development of tourism village in accordance with the pattern of the PIR.

Goals and targets of village tourism development among others:

1. Supporting the government programs in tourism with the provision of alternative programs.

2. Exploring the village potentials for the development of the local community.

3. Expanding employment and business fields for the society. 


\section{METHODS}

This research was conducted at Tourism Village of Tamansari in Ciapus, Bogor. The aspects used in this research was to create souvenir creativity as a support to tourist attraction in this tourism village considering that the village has not had the souvenir creativity they can produce and trade as a souvenir for the incoming tourists. In addition, this study also explored the constraints both in the manufacture and the availability of raw materials.

This research used qualitative descriptive research methods where the data were taken through the process of interviewing with community leaders, tourists and managers of attractive sites in Tamansari village to obtain accurate results to be served as informative data for the research discussion. Qualitative approach only focuses on one variable or one object of research because the target was the depth of the variable. In the implementation of methods involved in a qualitative approach requires the participatory of researchers in research activities because they are also concurrently as decision makers in setting some important things when the collection of data and information is conducted. Data validation (data validity test) in qualitative research has unequal connotation with validation in quantitative research, not parallel with reliability (stability test and consistency of respondent) and with generalizability (Creswell, Jhon W., 2012). Qualitative validity is an examination of the accuracy of research results by applying certain procedures, while the qualitative reliability indicates the consistency of the researcher's approach when it is applied by other researchers (and) for different projects (Creswell, Jhon W., 2012). Sugiyono argued that the test of data validity in qualitative research includes credibility test, transferability test, reliability and conformability test. Data analysis performed on research was based on model analysis techniques of Miles and Huberman. There were three stages of activities performed, namely Reduction Data, Display Data and Conclusion.

\section{RESULT AND DISCUSSION}

The questionnaire data from 30 respondents at Nangka waterfall revealed that the majority of respondents were interested to buy unique souvenirs illustrating the attractive places. Unfortunately, the absence of souvenirs made the visitors, especially who live outside Bogor, could not bring the souvenirs. This should be a concern and the local people might use this opportunity to increase their income by making typical souvenirs in the future.

In addition, the majority of respondents said that the interesting souvenirs were t-shirts and bracelets. According to them, both souvenirs were a general souvenir that should be found on tourist attractions. As the authors pointed out above, the potential of making a cloth with a typical characteristic of Nangka waterfall could be an alternative choice for t-shirt craftsmen at Tamansari Village although the waterfall is not located within the village. Another thing to be considered was a place to sell the souvenirs.

Making souvenirs for tourists was highly recommended because many tourists always take a visit at weekend. T-shirts, key chains, tissue boxes, snacks made of the original farm of Tamansari Village area became the main alternative souvenirs because the market potential was dominated by young people and families who spent the weekend for resting from their daily activities. Batik is the identity of Indonesia and has been registered as a UNESCO world heritage. Indonesia has a variety of motifs and types of batik. Almost all Indonesian people knows batik. Bogor is a district with the majority of Sundanese ethnic, and has a variety of Batik motifs which can be made as a souvenir. The majority of visitors who are young people is now getting interested in souvenirs such typical batik. Based on the test analysis, there were some products that can be produced with batik fabric as the base materials such as bags, wallets and handphone casing. Batik Bogor indeed has the potential to be developed as a souvenir, not only in the form of shirts but also can be a variety of typical craft materials from Bogor such in Yogyakarta.

Institutional and community participation at Tamansari Village have still not existed. There were only few people who run the activity at the past and now it was no longer exist. It can be the input for the manager to make the village better. The participation of the community was also small. There were only few housewives who did not have any activity that participated by cultivating mushrooms and processing food from their agricultural products to sell. However, the results of the study found 
that the community had the potential to make souvenirs from handicrafts with intense mentoring. To make souvenirs, the surrounding community, especially the housewives, will be empowered through training and mentoring. The training covered the production of screen printing t-shirts, handicrafts with basic materials of typical Bogor batik as well as bag, wallet and mobile phone casing. Therefore, the community empowerment and the new employment for the surrounding community were expected to be more available.

\section{V.CONCLUSION}

Some souvenirs that have been previously planned got a positive response by consumers because they are eager to get a distinctive souvenir from Tamansari Village of Ciapus, Bogor. The souvenirs are the results of craft and creativity of the local community with typical characteristic of the local community. This had a positive impact for the sustainability of the development of the tourism village such providing jobs for local people to increase their income. In addition, the tourists would get the typical souvenirs of the village easier. There were some souvenirs in great demand by tourists who visited the village, namely clothes or shirts illustrating some of tourism destinations at the village and bracelets made by local communities. Bogor Batik in the form of bags, wallets and handphone casing was also in demand.

\section{REFERENCES}

Creswell, Jhon W.(2012). Research design pendekatan kualitatif, kuantitatif, dan mixed. Terjemahan oleh Achmad Fawaid. Yogyakarta: Pustaka Pelajar.

Sugiyono.(2009). Metode Penelitian Kuantitatif, Kualitatif dan R\&D.Bandung: Alfabeta.

Tosun.(2006). Expected Nature of Community Participation in Tourism Development. Turkey: School of Tourism and Hotel Management. 